\title{
Mobile Application Tutorial Hajj and Umroh on Android Smartphone
}

\author{
$1^{\text {st }}$ Nurhayati ${ }^{1}, 2^{\text {nd }}$ Herlino Nanang ${ }^{1}, 3^{\text {rd }}$ Siti Kholifah Faujiah $^{1}, 4^{\text {th }}$ Busman $^{2}$ \\ \{nurhayati@uinjkt.ac.id ${ }^{1}$, herlino.nanang@uinjkt.ac.id ${ }^{1}$, siti.kholifah@mhs.uinjkt.ac.id', \\ busman.sjam@gmail.com²
}

UIN Syarif Hidayatullah, Department of Informatics ${ }^{1}$, Jakarta, Indonesia, Department of Management, School of Economics Gotong Royong, Jakarta, Indonesia ${ }^{2}$

\begin{abstract}
KBIH as government partners in order to realize and Umrah pilgrims are independent and have coaching institute rituals of Hajj are very attractive to pilgrims and Umrah. One of the emerging KBIH is KBIH Al-Manafiyah North Cikarang Bekasi. However, knowledge of media used for training rituals of Hajj in KBIH uses contextual media in the form of guide books and leaflets paper. It is not yet effective and efficient because there is a guide book that is sometimes difficult to understand and the limited time to study it more deeply. Based on the problems, We wants to build a mobile application on the Android platform. It hoped able to provide guidance information Hajj and Umrah. It are not only comprehensive but also practical. Methodology application development using Rapid Application Development, which consists of three phases: planning, design and implementation workshop to design the UML (Unified Models Language) and developed using Android Framework SDK, the Java programming language, PHP is a server side programming language, MySQL as database, Google Maps. Based on these results with the application of the congregation can easily obtain information about the Hajj and Umrah guide practical.
\end{abstract}

Keywords: Hajj, Umrah, KBIH, Android Smartphone, Mobile Application, Java

\section{Introduction}

Technological developments are progressing very rapidly one of which is a mobile telecommunications device or a mobile phone that is marked by the birth of Smartphone technology. Smartphone (Smart Phones) is a new class of mobile phone technology that can facilitate the access and processing of data with significant computing power. Currently, there are several Smartphone technology base that has been popular among people such as Blackberry, iPhone, Symbian, and Android. Features available on the android Smartphone is capable of running a variety of applications making it easier for users to perform various activities of life one of them presenting your information Hajj and Umrah.

Hajj is the fifth pillar of Islam after the creed, prayer, almsgiving and fasting. The pilgrimage is a visit to the House (Ka'bah) to do some good deeds such as tawaf, sa'i, before staying in Arafat, mabit and several other practice period, in order to meet the call of Allah and His pleasure expecting. In accordance with the word of God which means: " Indeed, the first House [of worship] established for mankind was that at Makkah - blessed and a guidance for the worlds.." (QS. Ali 'Imran [3] : 96). ${ }^{[1]}$ Travel Hajj and Umrah requires mental and 
physical readiness is good, if not pilgrims and Umrah will feel there is no time, stress and always short of time and information. For that, they need KBIH. ${ }^{[2]}$

$\mathrm{KBIH}$ existence as government partners in order to realize the pilgrims / Umrah independent and has become very popular institution or Umrah pilgrims. One of the emerging $\mathrm{KBIH}$ is KBIH Al-Manafiyah North Cikarang Bekasi. However, knowledge of media used for training rituals of Hajj are currently using contextual media in the form of guide books and leaflets paper. It turned out to be ineffective and inefficient because there are guidebooks that are sometimes difficult to understand and the limited time to study it more deeply. Based on the background that has been presented, the authors compiled research entitled: Mobile Application Tutorial Hajj and Umrah on Android Smartphone.

\section{Theoritical}

\subsection{Smartphone}

Smartphone are cellular phones with unlimited capabilities for communication via telephone and text messaging, but also to perform functions as well as computers. Smartphone terminology was first used in 1997 by the manufacturer Ericson to distinguish one of their products in the form of Penelope GS88 with a feature phone that was commonly marketed at the time. One significant thing that distinguishes Smartphone from feature phones is the use of application programming interfaces (APIs) that support the development and installation of applications from third parties that are integrated with the operating system and hardware. [7]

\subsection{Android}

Android is an operating system for Linux-based mobile devices that includes operating systems, middleware, and applications. Android provides an open platform for developers to create their applications. [5]

\subsection{Rapid Application Development (RAD)}

Rapid Application Development (RAD) is an incremental software development model, especially for short work times.[6] RAD (Rapid Application Development) is an objectoriented approach to the development of a system that includes a method development and softwares.[4]

There are 3 phases in RAD involving analysts and users in the assessment phase, design, and implementation of the following:

1. Requirements Planning Phase

In this phase, users and analysts meet to identify objectives of the application or system and to identify the information requirements arising from these goals..

2. Design Workshop RAD

This phase consists of the user's design phase and construction phase. Workshop design here is to work with users to design the system and after that build the system.

3. Implementation phase

In this phase built, approved and filtered new systems or parts of systems tested and then introduced to the organization.

\subsection{Unified Modelling Language (UML)}


UML is a "Language" which has become the industry standard for visualization, designing and documenting software systems. UML offers a standard for designing a system model. Using UML can create models for all types of software applications, where the application can run on any hardware, operating system and network, and is written in any programming language.[8]

\subsection{Java}

Java is an open source, so the following program source code used for free software development is downloaded and freely modified. In other words, Java can be used on various platforms (multiplatform). Java supports the latest software development features such as object oriented programming (OOP). Java has a better level of security than most other programming languages. [3]

\section{Methods}

\subsection{Smartphone}

1. Library Studies

2. Field Study

a. Observations (Observation)

b. Interview (Interview)

c. questionnaires

3. Similar Literature.

\subsection{Smartphone}

The method of developing a Hajj and Umrah guidance system uses Rapid Application Development (RAD), which has the following stages [4] :

1. Requirements Planning Phase

2. Design Workshop Implementation phase

\section{Result and Discussion}

After the text edit has been completed, the paper is ready for the template. Duplicate the template file by using the Save As command, and use the naming convention prescribed by your conference for the name of your paper. In this newly created file, highlight all of the contents and import your prepared text file. You are now ready to style your paper; use the scroll down window on the left of the MS Word Formatting toolbar.

\subsection{Requirements Planning Phase}

The planning phase the conditions that need to be considered are as follows:

- Identification of running system analysis

The author identifies the current system analysis in KBIH Al-Manafiyah, namely the media used in conveying the Hajj manasik learning today using contextual media.

- Determine the purpose of system development

In this case the author determines the goals that must be met from the system that is made so that it can satisfy the user 
Determine the system features that will be created

\subsection{Design Workshop RAD}

The design workshops have two. They are:

a. Phase designing user

This stage is the design stage of the proposed system in order to run well and is expected to address the problems that exist. Steps being taken are as follows:

\section{Design process}

The process design stage used the UML (Unified Modeling) diagrams as tools. However, not all diagrams provided by UML are used to designing this system. We used only a few UML diagrams are used can support the design of this application. The diagram used as follows:

Creating Use Case Diagrams, the author describes the functional needs of the system

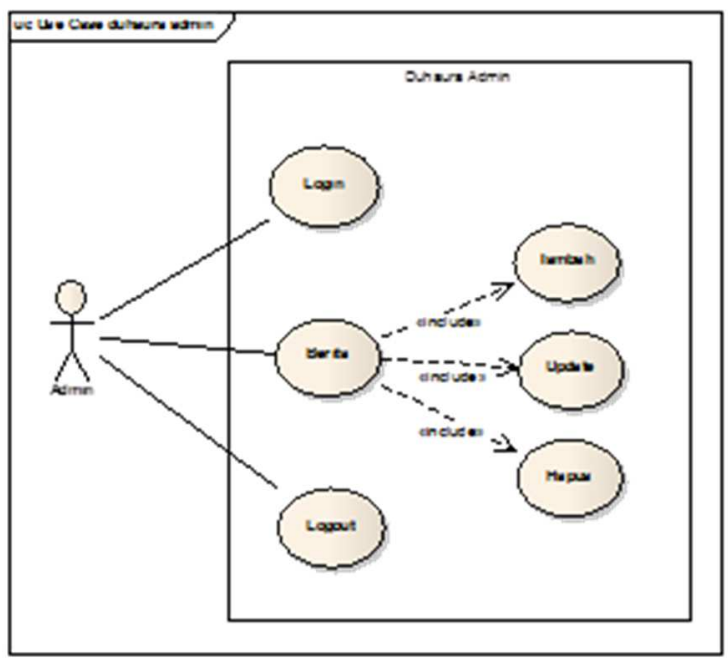

Figure 1. Use case Administrator 


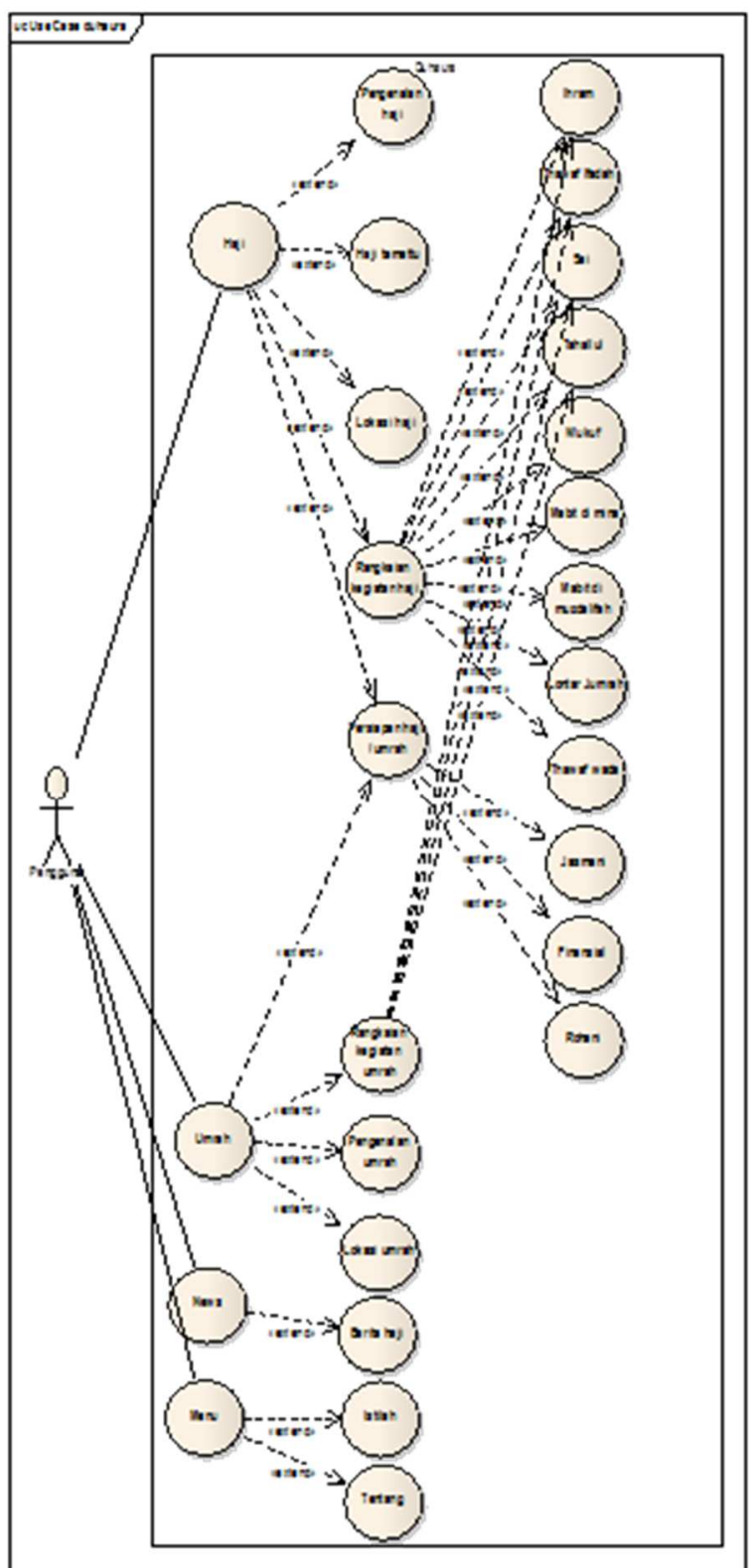

Figure 2. Use case User

- Creating Activity Diagrams, We describe the flow of what the user activities and systems, and also in view of how objects work. Here is an example diagram Activity Log.

Here is a sample Activity Diagram Use case Menu Hajj. 


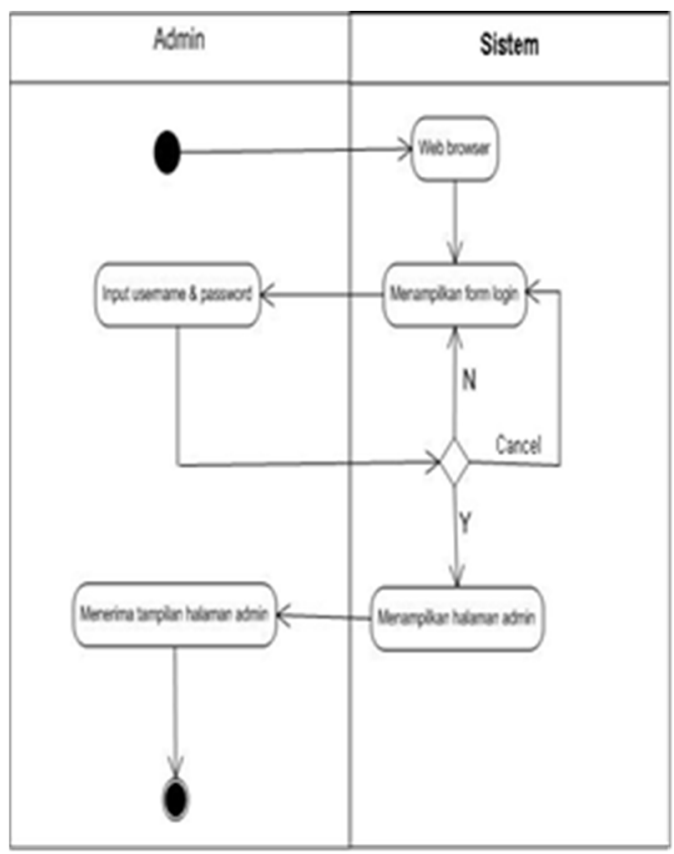

Figure 3. Activity diagram Login

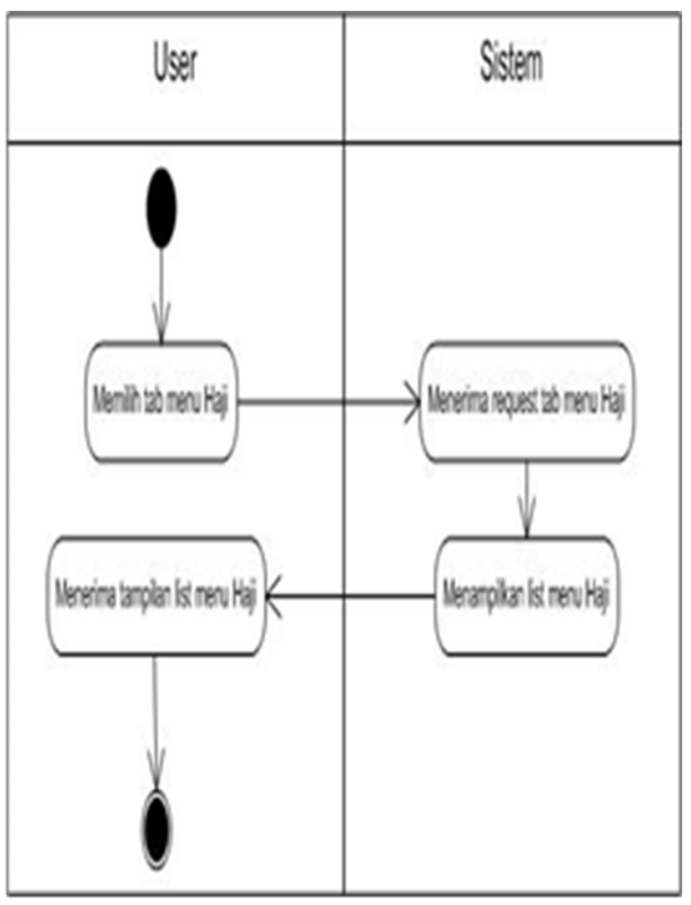

Figure 4. Activity diagram Haji Menu 
- Creating Sequence Diagrams, We explain in detail the time sequence of messages process carried out by the system.

Here is an example of a sequence diagram login and logout.

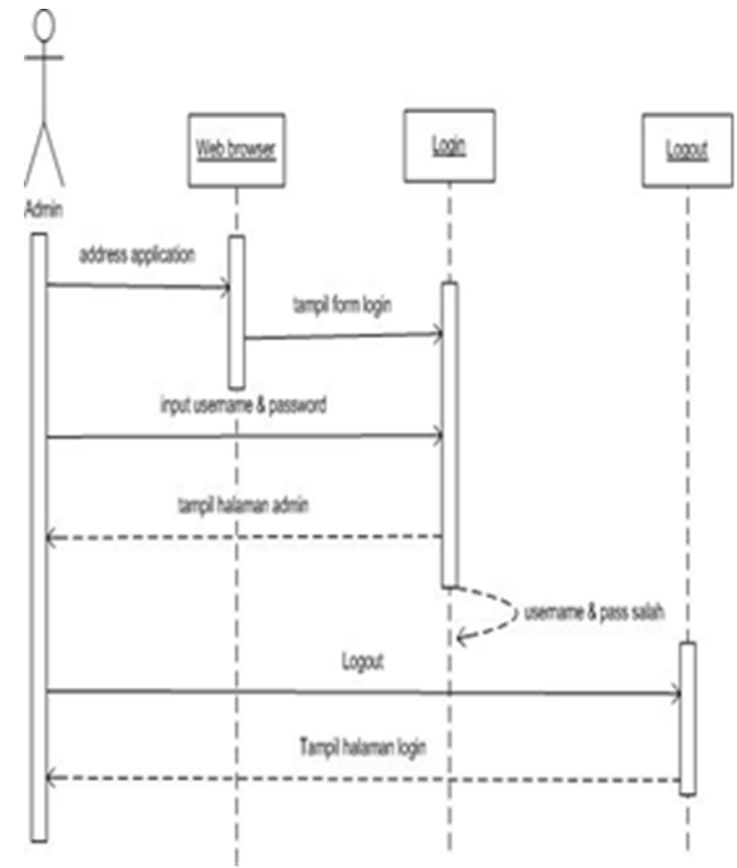

Figure 5. Sequence login and logout

Here is an example of a Sequence diagram Menu Hajj and Umrah 


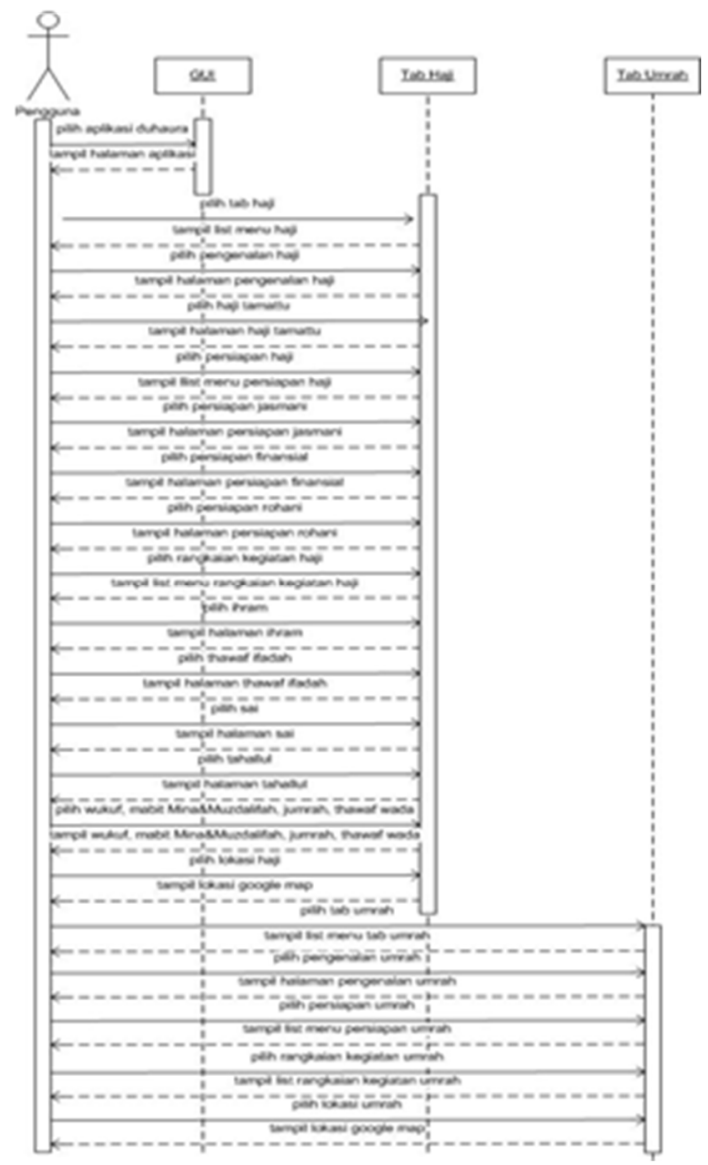

Figure 6. Sequence of Hajj and Umrah Menu

- Creating Class Diagrams, We visualize the structure of classes of a system and show the relationship between classes 


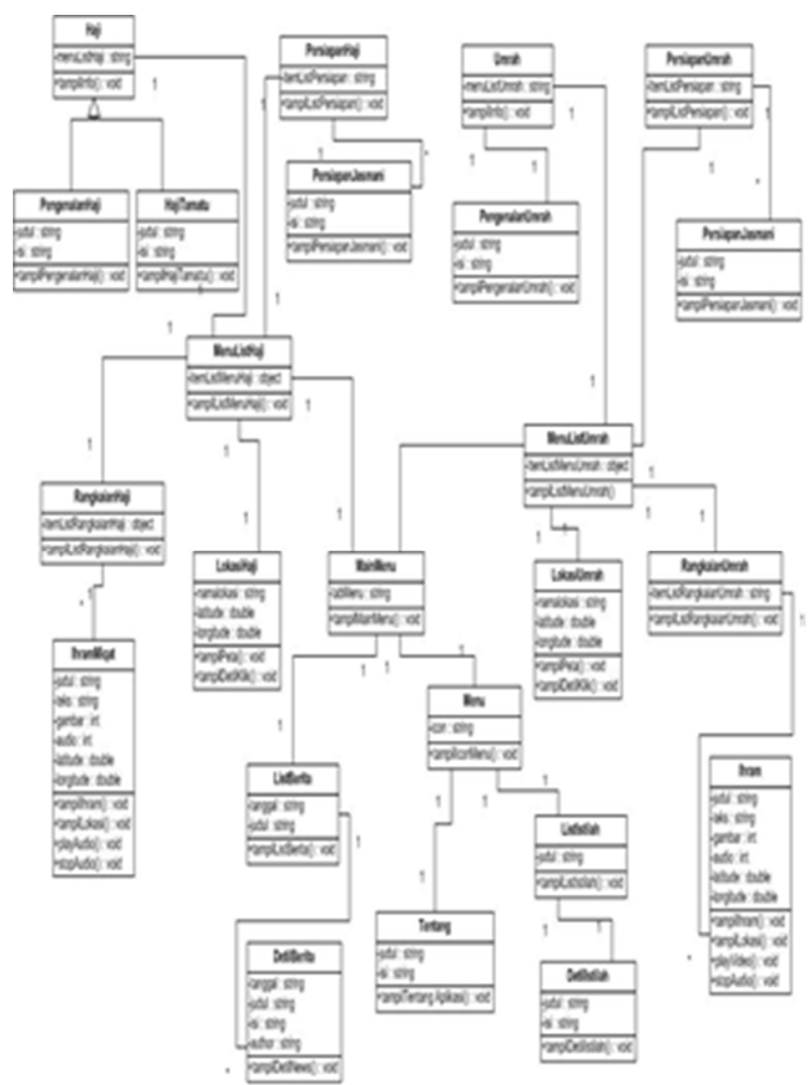

Figure 7. Class diagram

2. Database Design

The Database Design phase, we defined entities associated with information Hajj and Umrah guide and conduct of the entity database design has been obtained. Database to be designed is composed of table's duhaura news and admin tables.

\section{Design Interface}

The design phase interface, we designed the user interface to suit the user's needs so that this information can be used optimally by the users. Here is an example of the design interface pilgrim menu tab. 


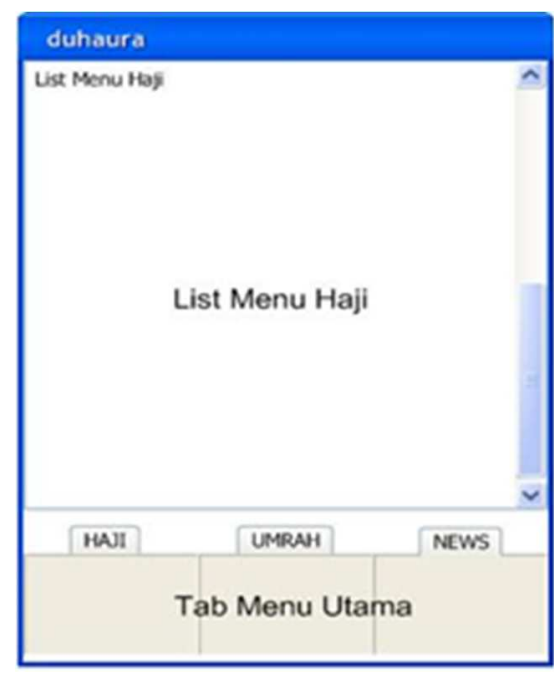

Figure 8. GUI Menu

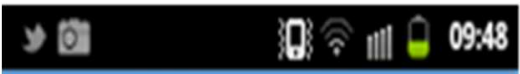

duhaura

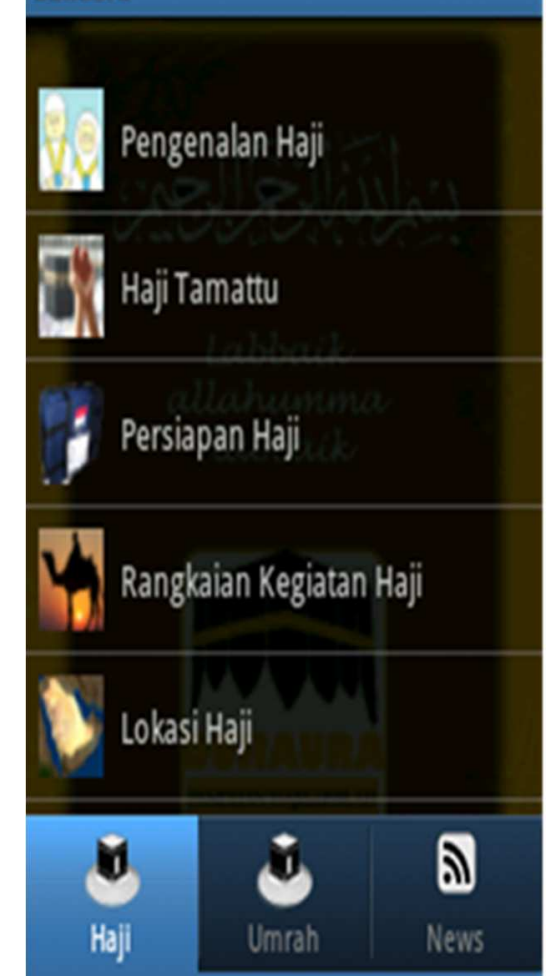

Figure 9. Hajj and Umrah Aplication

b. Construction phase 
At this stage a presentation of the results of the design into the program. In this stage, the authors use the Java programming language using Eclipse Indigo platform and the Android Emulator for hajj guide feature, then using the programming language PHP to connect to a MySQL database for Hajj news features [3].

\subsection{Implementation Phase}

At this stage, the authors conducted several phases of implementation are:

a. Application server hosting the Internet

We install the application server API, backend system (dashboard) hosted the www.000webhost.com to be accessible online for news features pilgrimage.

b. Installing the android handset

We install the Smartphone or Android handset.

c. Testing or application testing Blackbox testing

The Blackbox Testing is input / output testing. It is testing conducted to demonstrate that each of these functions fully operational, at the same time looking for errors in each function.

\section{Conclusion}

The Conclusions are:

1. This mobile application can facilitate the Muslims especially the travelers in obtaining your information Hajj and Umrah rituals in order to be able to perform well, smoothly, and it is valid according to Islamic guidelines so as to obtain a Mabrur pilgrimage, ameen.

2. That mobile applications as a tool capable of becoming one of the alternative solutions to problems that exist and can be useful to provide guidance information Hajj and Umrah . They are practical and can be understood easily by the Muslims, especially the pilgrims who can be used via the android smartphone.

\section{Suggestion}

The Suggestions are:

1. The development of similar systems in the form of other mobile platforms, (Symbian, J2me, Blackberry, iPhone and Windows Mobile).

2. Synchronization feature development to application server so that the content can be updated automatically via the Internet so that the form of dynamic data.

3. Development discussion of applications in all sorts of Hajj as Hajj pilgrimage Ifrad and Qiran.

4. Multilingual development to be used more widely

\section{References}

[1] Quran Kemenag. Ayat Al-Quran. Obtained on 13nd August 2018 http://www.qurankemenang.go.id 
[2] Departemen Agama RI Direktorat Jenderal Penyelenggaraan Haji dan Umrah. Tuntunan Praktis Perjalanan Ibadah Haji. Jakarta: Departemen Agama RI, 2017.

[3] Hudaya, Kharisman Kholid. Cara Cepat Menguasai Java Desktop dengan Metode Pro-OOP. Yogyakarta: CV. Andi, 2015.

[4] Kendall \& Kendall. System Analysis And Design. London: Pearson International Edition 7th Edition, 2008.

[5] Masruri, M. Hilmi. Aplikasi Android dalam 5 Menit Edisi Revisi, Jakarta: PT Elex Media Komputindo, 2016.

[6] Rosa, A.S., and M. Shalahuddin. 2016. Rekayasa Perangkat Lunak (Terstruktur dan Berorientasi Objek). Bandung: Informatika

[7] Safaat, Nazruddin. Pemograman Aplikasi Mobile Smartphone dan Tablet PC Berbasis Android. Bandung: Informatika, 2012.

[8] Yurindra. 2017. Software Engineering. Yogyakarta. DeepublishM. Young, The Technical Writer's Handbook. Mill Valley, CA: University Science, 1989. 